\title{
Pengaruh Persentase Serat Pelepah Pisang Terhadap Sifat Fisik dan Mekanik Papan Semen-Foam agent
}

\author{
Randa*, Alimin Mahyudin \\ Laboratorium Fisika Material \\ Fakultas Matematika dan Ilmu Pengetahuan Alam Universitas Andalas \\ Kampus Unand Limau Manih, Padang,25163, Indonesia \\ *randaaja73@gmail.com
}

\begin{abstract}
ABSTRAK
Telah dilakukan penelitian tentang pengaruh persentase serat pelepah pisang terhadap sifat fisik dan mekanik papan semen. Persentase serat yang digunakan adalah $0 \%, 0,2 \%, 0,4 \%, 0,6 \%$ dan $0,8 \%$. Penambahan serat pelepah pisang dan foam agent dapat membuat papan semen menjadi lebih ringan dibandingkan dengan papan Glass-Fiber Reinforced Cement (GRC) yang komersial. Hasil pengujian menunjukkan nilai densitas berbanding terbalik dengan porositas dimana nilai minimum densitas yaitu $1,27 \mathrm{~g} / \mathrm{cm}^{3}$ terdapat pada serat $0,8 \%$. Nilai porositas tertinggi terdapat pada persentase $0,8 \%$ yaitu $33,93 \%$. Kuat tekan maksimum yaitu $82,76 \mathrm{~kg} / \mathrm{cm}^{2}$ terdapat pada persentase serat $0,4 \%$ dan telah memenuhi SNI 03-3449-2002, sedangkan untuk nilai kuat lentur maksimum yaitu 77,40 $\mathrm{kg} / \mathrm{cm}^{2}$ terdapat pada komposisi serat $0,6 \%$. Hasil pengujian menyatakan papan semen serat pelepah pisang - foam agent telah memenuhi SNI 03-3449-2002 dengan nilai densitas $<1,90 \mathrm{~g} / \mathrm{cm}^{3}$.

Kata kunci: papan semen, densitas, porositas, kuat tekan, kuat lentur, serat pelepah pisang.
\end{abstract}

\begin{abstract}
Research about the effect of banana midrib fiber percentage for the physical and mechanical properties of cement board has been conducted. The fibers percentage used are $0 \%, 0.2 \%, 0.4 \%, 0.6 \%$ and $0.8 \%$. Addition of banana midrid fiber and foam agent makes cement boards become lighter compare to the commercial Glass-Fiber Reinforced Cement (GRC) board. The result of density values inversely proportional to porosity. The lowest density value was obtained $1.27 \mathrm{~g} / \mathrm{cm}^{3}$ in the sample with fiber percentage of $0.8 \%$ and the highest porosity value of $33.93 \%$ in the sample with a fiber percentage of $0.8 \%$. The maximum compressive strength was found in samples with a fiber percentage of $0.4 \%$ which was $82.76 \mathrm{~kg} / \mathrm{cm}^{2}$ and requared SNI 03-3449-2002 standards, while the highest flexural strength value was obtained in samples with 0,6\% fiber percentage which was $77.40 \mathrm{~kg} / \mathrm{cm}^{2}$. Results show that the cement board made from banana midrib fiber-foam agent has requared the SNI 03-3449-2002 standard with the density value of $<1.90 \mathrm{~g} / \mathrm{cm}^{3}$.

Keywords: cement board, density, porosity, compressive strength, flexural strength.
\end{abstract}

\section{PENDAHULUAN}

Kemajuan sains dan teknologi membuat penelitian di bidang material komposit semakin banyak dikembangkan khususnya salah satu pada bidang konstruksi bangunan. Perkembangan material komposit semakin pesat dikarenakan sifat material tersebut yang dapat direkayasa sehingga menghasilkan material baru yang lebih unggul dari material sebelumnya. Saat ini aplikasi material komposit yang beredar di pasaran salah satunya adalah komposit papan berupa GRC (Glass-Fiber Reinforced Cement) yang digunakan untuk pembuatan plafon bangunan, panel dinding, partisi ruangan dan sebagainya. GRC terdiri dari campuran semen, pasir dengan agregat halus dan air yang ditambah dengan serat kaca atau fiber glass. Penggunaan serat kaca pada GRC menjadi perhatian saat ini, karena serat kaca memiliki harga yang mahal dan tidak terurai di dalam tanah sehingga berdampak pada lingkungan (Shiddieq, 2017). Selain itu, GRC yang beredar di pasaran memiliki densitas yang tinggi yaitu $1,9-2,1 \mathrm{~g} / \mathrm{cm}^{3}$ (Bartos, 2017). Permasalahan tersebut membuat peneliti untuk merekayasa material GRC menjadi papan semen menggunakan serat alam yaitu serat pelepah pisang dan untuk memperoleh kuat tekan dan kuat lentur yang tinggi.

Serat pelepah pisang mempunyai sifat mekanik yang lebih kaku, tangguh dan lebih kokoh. Selain itu, serat pisang memiliki rongga antar serat (Yuhazri, 2010). Serat pelepah pisang merupakan serat yang mempunyai sifat yang lebih baik, kandungan selulosanya 63\%$64 \%$ hemisesulosa 20\%,kandungan lignin 5\%, kekuatan tarik rata-rata $600 \mathrm{Mpa}$, modulus tarik 
rata-rata 17,85 Gpa dan pertambahan panjang seratnya sekitra 30,92-40,93 cm (Lokantara, 2007).

Malau dkk. (2015), juga melakukan penelitian tentang kualitas papan partikel batang pisang berdasarkan variasi kadar perekat phenol formaldehida. Hasil penelitian ini menunjukkan bahwa variasi perekat terbaik adalah $16 \%$ karena terjadi penyebaran filler yang lebih merata dibandingkan dengan variasi $8 \%, 10 \%, 12 \%, 14 \%$. Kuat lentur yang didapat 27,6 $\mathrm{kg} / \mathrm{cm} 2$ dan kuat tekan 70,7 kg/cm2 masih belum memenuhi standar SNI 03-2150-2006.

Nanang (2014), Analisa pengaruh variasi fraksi volume volume terhadap densitas dan kekuatasn tarik serat pelepah pisang-Epoksi. Hasil penelitian ini menunjukan bahwa densitas terendah berada pada komposit dengan fraksi volume $0,6 \%\left(1,08 \mathrm{gr} / \mathrm{cm}^{2}\right)$, sedangkan densitas tertinggi terdapat pada fraksi volume $0,2 \%$ serat $\left(1,38 \mathrm{gr} / \mathrm{cm}^{2}\right)$. Untuk pengujian tarik, nilai kekuatan maksimum tertinggi berada pada komposit dengan fraksi volume $0,6 \% \quad(32,27$ $\mathrm{N} / \mathrm{mm}^{2}$ ), Sedangkan nilai kekuatan minimum berada pada posisi komposit dengan fraksi volume $0,2 \%\left(28,27 \mathrm{~N} / \mathrm{mm}^{2}\right)$.

Penelitian dengan menggunakan foam agent telah dilakukan oleh Murtono (2015), Dalam penelitiannya variasi foam agent yang ditambahkan pada komposisi campuran pasta beton adalah $0 \mathrm{~L} / \mathrm{m}^{3} ; 0,6 \mathrm{~L} / \mathrm{m}^{3} ; 0,8 \mathrm{~L} / \mathrm{m}^{3}$ dan $1,0 \mathrm{~L} / \mathrm{m}^{3}$ dari volume beton sebelum pencampuran. Dari hasil penelitiannya Dari kuat tekan tertinggi dicapai beton dengan kandungan foam agent $0,6 \mathrm{~L} / \mathrm{m}^{3}$ sebesar $4,02 \mathrm{MPa}$, kuat lentur balok beton dengan kandungan foam agent $0,6 \mathrm{~L} / \mathrm{m}^{3}$ sebesar 0,738 Mpa.

\section{METODE}

Teknik penelitian yang digunakan adalah metode two dimensional reinforcement dengan beberapa tahapan, diantaranya. Persiapan yang dilakukan adalah pengolahan serat pelepah pisang dengan cara mengambil serat pelepah pisang dari bagian pelepah pisng. Serat pelepah pisang dipotong dengan ukuran $1 \mathrm{~cm}$. Serat pisang kemudian diberikan perlakuan alkali dengan cara direndam dengan larutan $\mathrm{NaOH} 5 \%$ selama 2 jam. Kemudian serat dibilas dengan aquades untuk menghilangkan kandungan $\mathrm{NaOH}$ yang tersisa. Selanjutnya serat dikeringkan pada suhu ruangan untuk menghilangakan kadar air yang tersisa, dan setelah kering serat siap digunakan dalam proses pembuatan sampel.

Tahap - tahap pembuatan papan semen adalah sebagai berikut, tahap pertama adalah pembuatan pasta beton dengan mencampurkan semen, pasir. Semen dan agregat diaduk hingga merata kemudian air dituangkan sedikit demi sedikit dengan perbandingan air dan semen 0,4:1. Foam Agent diaduk dengan air hingga membentuk busa, hasil adukan digabungkan ke dalam campuran mortar. Pasta beton kemudian dituangkan kedalam cetakan dengan ukuran $5 \mathrm{~cm} x$ $5 \mathrm{~cm} \times 1 \mathrm{~cm}$ untuk uji densitas, porositas dan kuat tekan untuk uji kuat lentur digunakan ukuran cetakan $20 \mathrm{~cm}$ x $5 \mathrm{~cm}$ x $1 \mathrm{~cm}$. Permukaan sampel diratakan dengan sendok semen dan didiamkan dalam cetakan selama $24 \mathrm{jam}$. Setelah itu sampel uji yang terbentuk dikondisikan pada suhu ruang selama 28 hari sebelum digunakan untuk pengujian sesuai standar.

\subsection{Pengujian Densitas}

Nilai densitas dilakukan dengan mengukur massa kering sampel dalam satuan gram dan mengukur panjang, lebar serta tebal sampel untuk mendapatkan volumenya dalam satuan $\mathrm{cm}^{3}$. Nilai densitas sampel uji dihitung menggunakan Persamaan 1.

$$
\rho=\frac{m}{v}
$$

dengan $\rho$ adalah densitas $\left(\mathrm{g} / \mathrm{cm}^{3}\right), m$ adalah massa $(\mathrm{g}), V$ adalah volume $\left(\mathrm{cm}^{3}\right)$.

\subsection{Pengujian Porositas}

Pengujian porositas dilakukan pada sampel uji daya serap air. Perhitungan porositas dapat dilakukan denggan menggunakan Persamaan 2. 


$$
\operatorname{Porositas}(\%)=\frac{m_{b}-m}{V} \frac{1}{\rho}
$$

dengan $P$ adalah porositas $(\%), m_{b}$ adalah massa basah $(\mathrm{g}), m$ adalah massa sampel kondisi kering $(\mathrm{g}), V$ adalah volume sampel $\left(\mathrm{cm}^{3}\right)$ dan $\rho$ adalah massa jenis air yaitu $1 \mathrm{~g} / \mathrm{cm}$.

\subsection{Pengujian Kuat Tekan}

Mula-mula sampel diukur panjang, lebar dan tebal dengan menggunakan jangka sorong dan hasil dicatat. Kemudian sampel uji diberi beban secara vertikal dan dicatat perubahan sampel akibat diberi beban maksimum secara vertikal hingga sampel uji retak. Nilai kuat tekan dapat dihitung menggunakan Persamaan 3.

$$
f_{c}=\frac{P}{A}
$$

dengan $f_{c}$ adalah kuat tekan $\left(\mathrm{kg} / \mathrm{cm}^{2}\right), P$ adalah beban retak maksimum sampel $(\mathrm{kg})$ dan $A$ adalah luas permukaan sampel $\left(\mathrm{cm}^{2}\right)$.

\subsection{Pengujian Kuat Lentur}

Mula-mula sampel diukur lebar dan tebalnya dengan jangka sorong dan dicatat hasil pengukuran. Kemudian dilakukan pengujian kuat lentur menggunakan mesin UTM dengan meletakkan sampel secara mendatar pada tumpuan. Sampel diberikan beban pada bagian pusat dan dicatat perubahan sampel akibat diberi beban secara vertikal hingga sampel uji patah. Nilai kuat lentur dapat dihitung menggunakan Persamaan 4.

$$
f_{r}=\frac{3 m_{p} s}{2 L T^{2}}
$$

dengan $f_{r}$ adalah kuat lentur $\left(\mathrm{kg} / \mathrm{cm}^{3}\right), m_{p}$ adalah beban patah maksimum $(\mathrm{kg}), s$ adalah jarak tumpuan $(\mathrm{cm}), L$ adalah lebar sampel uji $(\mathrm{cm})$ dan $T$ adalah tinggi sampel $(\mathrm{cm})$.

\section{HASIL DAN DISKUSI}

\subsection{Densitas}

Gambar 1 menunjukan nilai densitas variasi persentase serat pelepah pisang pada papan semen. Penambahan serat $0 \%, 0,2 \%, 0,4 \%, 0,6 \%$ dan $0,8 \%$ yang menurun seiring pertambahan persentase serat pelepah pisang. Sampel dengan persentase serat $0 \%$ memiliki densitas tertinggi yaitu $1,66 \mathrm{~g} / \mathrm{cm}^{3}$. Dengan nilai densitas terendah berada pada persentase $0,8 \%$ yatu $1,27 \mathrm{~g} / \mathrm{cm}^{3}$, hal ini dikarenakan penambahan Serat pelepah pisang $0,8 \%$ karena adanya penambahan serat dan foam agent yang terdapat pada pasta. Selain itu, foam agent juga menjadi faktor penting selain menstabilkan dalam pencampuran menyebabkan terbentuknya gelembung-gelembung pada proses pengadukan sehingga membuat berat jenis beton menjadi kecil (Simbolon, 2015). Papan semen variasi serat pelepah pisang memenuhi standar mutu SNI 03-3449-2002 dengan nilai $<1,90 \mathrm{~g} / \mathrm{cm}^{3}$. Hasil pengujian yang diperoleh dari papan semen variasi serat pelepah pisang memenuhi SNI 03-3449-2002 dengan nilai densitas $<1,90 \mathrm{~g} / \mathrm{cm}^{3}$, dan nilai densitas papan semen ini lebih kecil dibandingkan dengan papan GRC yang nilainya $1,77 \mathrm{~g} / \mathrm{cm}^{3}$. 


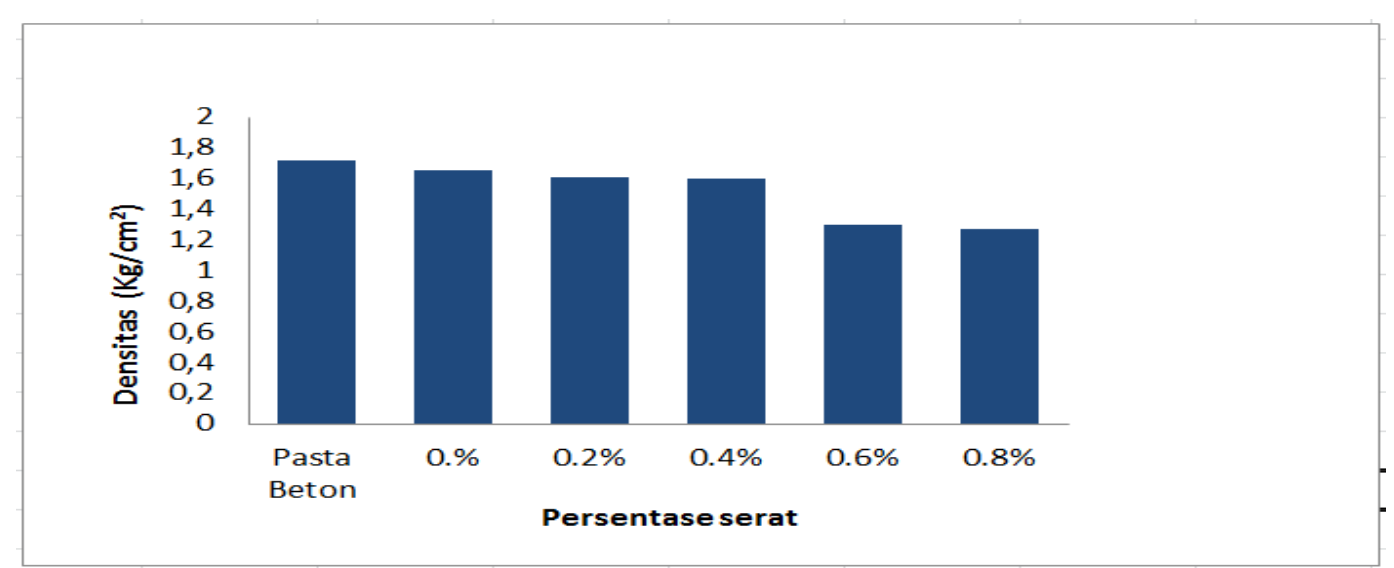

Gambar 1 Pengaruh persentase serat Pelepah pisang terhadap densitas papan semen.

\subsection{Porositas}

Gambar 2 menunjukan nilai porositas pada papan semen variasi persentase serat pelepah pisang. Hal yang menyebabkan tingginya nilai porositas pada persentase $0,8 \%$ yaitu penambahan serat yang terlalu banyak sehingga munculnya rongga-rongga pada papan semen. Terdapatnya rongga-rongga udara menyebabkan papan memiliki densitas rendah dengan nilai daya serap air yang tinggi. Nilai porositas berbanding lurus dengan nilai daya serap air yang didapatkan. Nilai terendah berada pada persentase $0 \%$ yaitu $19,44 \%$ dengan nilai tertinggi pada persentase $0,8 \%$ yaitu $33,93 \%$.

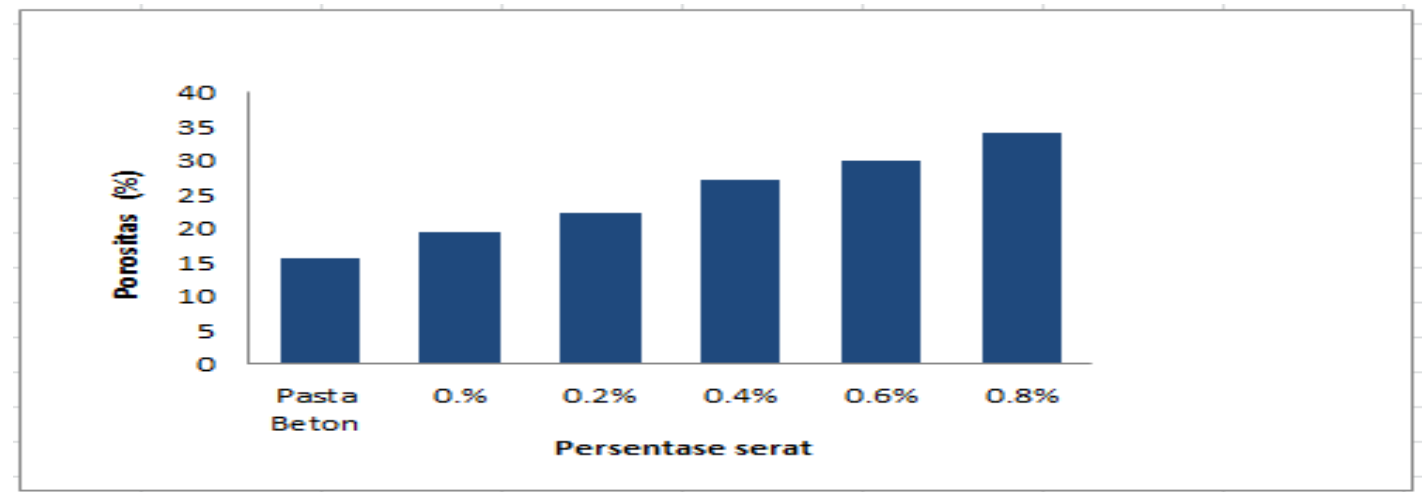

Gambar 3 Pengaruh persentase serat pelepah pisang terhadap nilai porositas papan semen.

Hal yang menyebabkan tingginya nilai porositas pada persentase $0,8 \%$ yaitu penambahan serat yang terlalu banyak sehingga munculnya rongga-rongga pada papan semen. Terdapatnya rongga-rongga udara menyebabkan papan memiliki densitas rendah dengan nilai daya serap air yang tinggi. Nilai porositas berbanding lurus dengan nilai daya serap air yang didapatkan. Nilai terendah berada pada persentase $0 \%$ yaitu $19,44 \%$ dengan nilai tertinggi pada persentase $0,8 \%$ yaitu $33,93 \%$.

\subsection{Kuat Tekan}

Gambar 3 menunjukan nilai kuat tekan yang didapatkan pada papan beton ringan variasi persentase serat pelepah pisang. Penambahan serat yang berlebihan akan membuat nilai kuat tekan papan semen menurun. Nilai kuat tekan menurun karena ikatan antarmuka (interface) antara serat dan matriks menjadi lemah karena jumlahnya yang semakin banyak. Lemahnya ikatan antarmuka berdampak pada kekuatan papan semen yaitu menjadikan papan tidak mampu menahan beban yang diberikan. Dapat dilihat nilai maksimum penambahan serat pada papan semen terdapat pada persentase $0,4 \%$ yaitu $82,76 \mathrm{~kg} / \mathrm{cm}^{2}$. Dengan nilai terendah pada persentase $0,6 \%$ yaitu $6,20 \mathrm{~kg} / \mathrm{cm}^{2}$. 


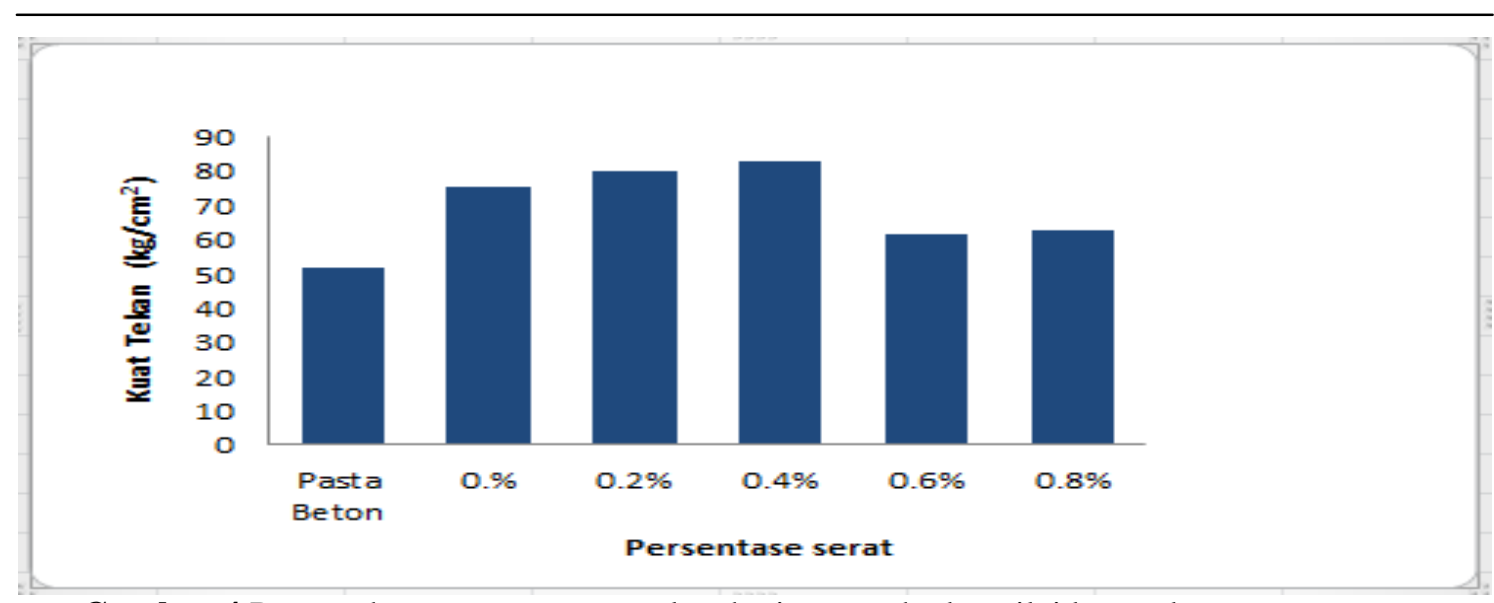

Gambar 4 Pengaruh persentase serat pelepah pisang terhadap nilai kuat tekan papan semen.

Penambahan serat yang berlebihan akan membuat nilai kuat tekan papan semen menurun. Nilai kuat tekan menurun karena ikatan antarmuka (interface) antara serat dan matriks menjadi lemah karena jumlahnya yang semakin banyak. Lemahnya ikatan antarmuka berdampak pada kekuatan papan semen yaitu menjadikan papan tidak mampu menahan beban yang diberikan. Dapat dilihat nilai maksimum penambahan serat pada papan semen terdapat pada persentase $0,4 \%$ yaitu $82,76 \mathrm{~kg} / \mathrm{cm}^{2}$. Dengan nilai terendah pada persentase $0,6 \%$ yaitu $6,20 \mathrm{~kg} / \mathrm{cm}^{2}$.

\subsection{Kuat Lentur}

Gambar 4 menunjukan nilai kuat lentur yang diperoleh pada papan semen variasi persentase serat pelepah pisang. Nilai kuat lentur maksimal diperoleh pada persentase $0,6 \%$ yaitu $77,40 \mathrm{~kg} / \mathrm{cm}^{2}$ dengan nilai terendah berada pada persentase $0 \%$ yaitu $54,90 \mathrm{~kg} / \mathrm{cm}^{2}$. Dapat dilihat bahwa penurunan nilai kuat lentur seiring dengan penambahan serat pelepah pisang. Hal ini dikarenakan penambahan serat yang relatif sedikit dapat menutupi rongga udara dan menggurangi keretakan sehingga papan semen dapat menahan beban hingga batas optimum yang menyebabkan terjadinya lentur dan deformasi yang relatif sedikit.

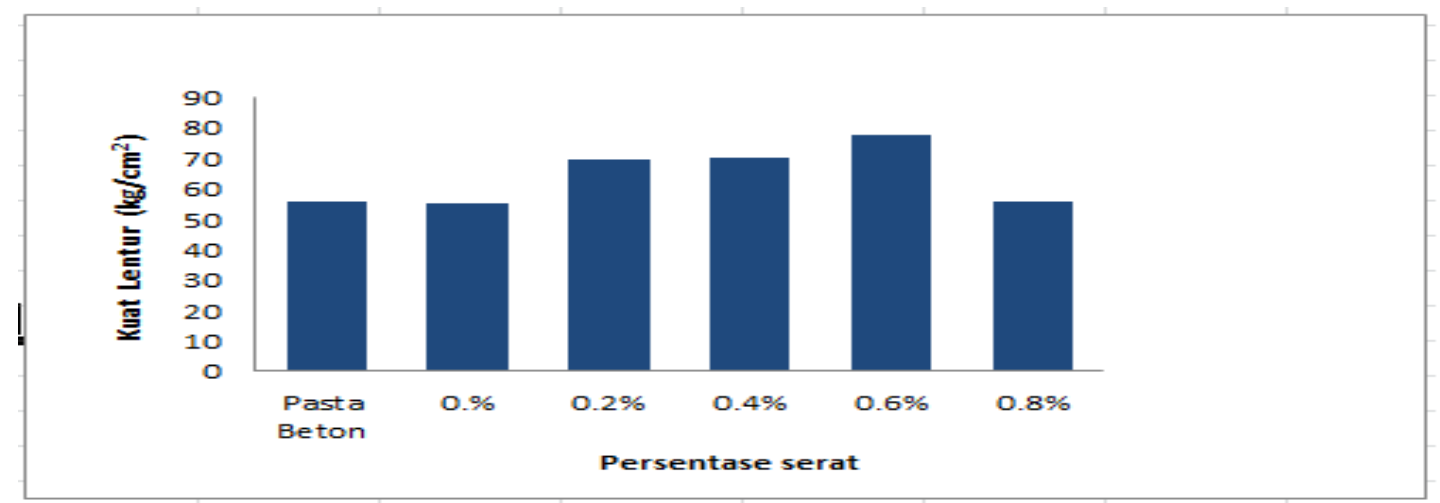

Gambar 5 Pengaruh persentase serat pelepah pisang terhadap nilai kuat tekan papan semen.

Kuat lentur menurun juga disebabkan karena ikatan antarmuka (interface) antara serat dan matrik menjadi lemah karena jumahnya yang semakin banyak. Lemahnya ikatan interface ini berdampak pada kekuatan sampel terhadap beban yang diberikan. Adapun dampaknya yaitu menjadi sampel tidak mampu menahan beban yang diberikan. Sehingga nilai kuat lentur yang dihasilkan akan menurun. Jika dibandingkan dengan standar mutu GRCA (Glassfibre Reinforceed Concrete Association) dengan nilai 203,947-305,915 kg/ $\mathrm{cm}^{2}$, papan beton ringan variasi serat pelepah pisang masih jauh dibawah GRCA. 


\section{KESIMPULAN}

Penambahan serat pelepah pisang berpengaruh terhadap sifat mekanik papan semenfoam agent. Nilai kuat tekan tertinggi dihasilkan oleh papan semen 0,4 \% sebesar 82,76 $\mathrm{kg} / \mathrm{cm}^{2}$. Nilai ini telah memenuhi standar mutu SNI 03-3449-2004, Sedangkan nilai kuat lentur tertinggi didapatkan pada persentase serat $0,6 \%$ dengan nilai $77,40 \mathrm{~kg} / \mathrm{cm}^{2}$ masih belum memenuhi standar yang dipasaran yaitu $144 \mathrm{~kg} / \mathrm{cm}^{2}$. Penamabahan serat pelepah pisang dan foam agent $0,06 \%$ membuat papan semen menjadi lebih ringan. Dari hasil pengujian sifat fisik, papan semen serat pelepah pisang dan foam agent memiliki nilai densitas yang lebih baik. Nilai optimum pada persentase serat $0,8 \%$ sebesar $1,27 \mathrm{~kg} / \mathrm{cm}^{3}$.

\section{DAFTAR PUSTAKA}

Badan Standardisasi Nasional (BSN), SN 03-3449-2002, Tata Cara Rencana Pembuatan Campuran Beton Ringan Dengan Agregat Ringan, Indonesia, 2002.

Badan Standarisasi Nasional (BSN), SNI 03-2105-2006, Papan Partikel, Indonesia,2006.

Bartos, P.J.M., 2017, Glassfiber Reinforced Concrete: A Review, IOP Conference Series: Material Science and Engineering, Scotland.

Nanang, E., 2014, Analisis Pengaruh Variasi Fraksi Volume terhadap Densitas dan Kekuatan Tarik Serat Pelepah Pisang-Epoksi, Jurnal Teknik Mesin, 5(2), Jurusan Teknik Mesin, Fakultas Mesin, Universitas Halu, Kediri.

Lokantara, P., 2007, Analisis Kekuatan Impact Komposit Polyester-Serat Tapis Kelapa DenganVariasi Panjang Dan Fraksi Volume Serat Yang Diberi Perlakuan $\mathrm{NaOH}$, FakultasTeknik, Universitas Udayana, Kampus Bukit Jimbaran, Bali, Indonesia.

Malau, J. C., Sucipto, T., dan Iswanto, A. H., "Kualitas Papan Partikel Batang Pisang Barangan Berdasarkan Variasi Kadar Perekat Phenol Formaldehida", Jurnal Kehutanan, 4(1), 2015, hal. 4-7.

Murtono, A., 2015, Pemanfaatan Foam Agent dan Material Lokal dalam Pembuatan Bata Ringan, Prosiding Seminar Nasional V Teknik Sipil, Universitas Muhammadiyah Surakarta, ISSN:2459-9727, Surakarta.

Renreng, I., Analisis Kekuatan Tarik Komposit Serat Kelapa (Cocos Nucifera) dengan Perlakuan Curcuma Domestica, Jurusan Mekanikal, Jurusan Teknik Mesin, Fakultas Mesin, Universitas Hasanuddin, No. 6, 2015, Makassar.

Shiddieq, A.S., 2017, Penggunaan Limbah Serabut Kelapa Sebagai Pengganti Serat Fiber pada Pembuatan Panel Dinding Glassfiber Reinforced Cement, Jurnal Rekayasa Teknik Sipil, 3(3), Jurusan Teknik Sipil, Universitas Negeri Surabaya. 